\title{
APPLICATIONS OF NANOSCALE MATERIALS IN THE FIELDS OF ELECTROCHEMISTRY AND PHOTOELECTROCHEMISTRY
}

\author{
G. CAMPET ${ }^{\mathrm{a}}$, A. DESHAYES ${ }^{\mathrm{b}}$, J.C. FRISON ${ }^{\mathrm{c}}$, N. TREUIL $^{\mathrm{a}}$ \\ and J. PORTIER ${ }^{\mathrm{a}}$
}

\begin{abstract}
anstitut de chimie de la Matière Condensée de Bordeaux CNRS, Université de Bordeaux I, Château Brivazac, Av. du Dr. A. Schweitzer - 33600 Pessac, France. ${ }^{b}$ Centre National d'Etude des Télécommunications, 38-40 rue du Général-Leclerc,

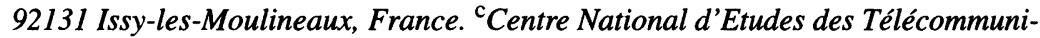
cations, 2 route de Trégastel, BP-40, 22301 Lanion, France
\end{abstract}

(Received 21 October, 1996; In final form 3 January, 1997)

We have illustrated the important role played by the nanoscale materials in three-up-to-date energy topics.

1/ The solar-to-electrical energy conversion in photoelectrochemical cells: we have shown two favorable situations for which photoelectrochemical cells using porous nanocrystalline films have high efficiencies.

$2 /$ The electrical energy storage in rechargeable rocking-chair lithium batteries: these systems, which use nanocrystalline materials, might be the next generation of rechargeable batteries showing higher capacity, cyclability, and safety than conventional lithium ion batteries.

3 / The energy saving with efficient electrochromic windows using nanocrystalline materials.

\section{INTRODUCTION}

The recent surge of interest in nanoscale materials is engendered by various reasons, one of them being the realization that the nanoscale materials often exhibit physical and chemical properties that are different from their bulk counterparts. For instance, when the nanoscale materials are in the form of finely grained powders or of nanocrystalline films, they offer, indeed, the obvious advantage to combine structural effect (inside grain structure) with surface effect or grain-boundary effect. This combination accounts for their original properties. 
The evolution of the electronic properties of metal oxides, when their crystallite-size decreases down to nanometer size, has been widely investigated [1]. Such an evolution study is not our purpose here.

One knows also that there are a large number of manufacturing processes leading to nanoscale materials [2]. Again, our purpose is not to describe or to review them.

We simply intend, here, to investigate the important role played by the nanoscale materials in the fields of electrochemistry and photoelectrochemistry. That will be illustrated using three up-to-date energy topics as a support (fig. 1):

- the solar-to-electrical energy conversion in photo-electrochemical cells using nanocrystalline films

- the electrical energy storage in rechargeable rocking-chair lithium batteries using either nanocrystalline powders or nanocrystalline films

- the energy saving with electrochochromic windows in which inorganic "nano - Crystalline - Insertion - Materials" intervene in film form

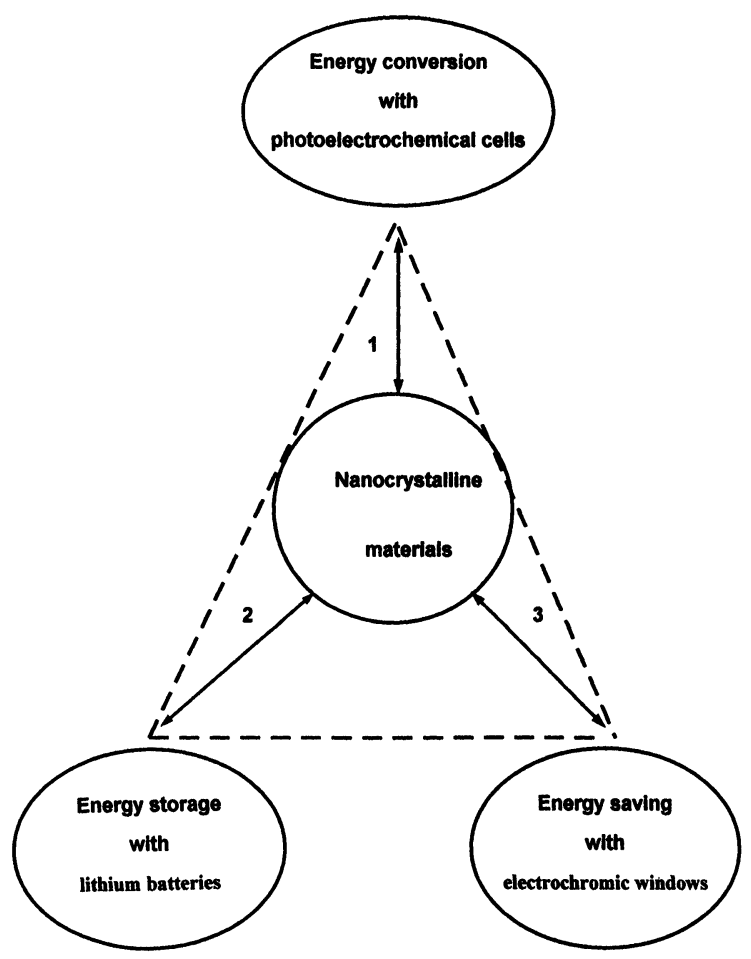

FIGURE 1 The "energy triangle" 


\section{THE SOLAR-TO-ELECTRICAL ENERGY CONVERSION IN PHOTOELECTROCHEMICAL CELLS USING NANOCRYSTALLINE FILMS}

First of all and for sake of clarity, we have illustrated in fig. 2 the general principle of a photoelectrochemical cell. Light illumination of the photoanode surface generates electron-hole pairs that can be separated by the electric field present in the band bending region (fig.). The conduction-band photoelectrons are directed through a charge collector into the external circuit where electrical work is done. The carriers are then returned back to the cell through the counter electrode. Between the counter electrode and the photoanode is an electrolyte containing a redox couple $R / R^{-}$. This redox electrolyte allows for charge transport between the two electrodes: the photoelectrons reduce $\mathrm{R}$ into $\mathrm{R}$, which diffuse from the counter electrode the photoanode; at the photoanode the photoholes oxydize $\mathrm{R}^{-}$into $\mathrm{R}$. The whole system is then closed. The cell voltage $\Delta \mathrm{V}$, observed under illumination, corresponds to the difference in the quasi-Fermi Level of the photoanode under illumination and the Nernst potential of the redox couple $\left(R / R^{-}\right)$used to mediate charge transfer between the electrodes [3].

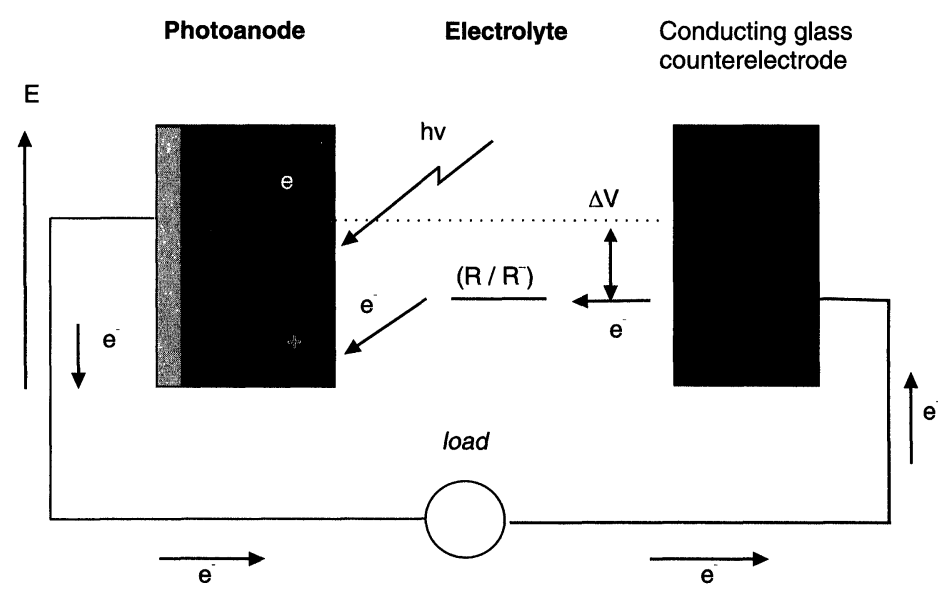

FIGURE 2 General principle of a photoelectrochemical cell

Semiconductor films with small crystal size normally have large recombination losses in photovoltaic cells. That is indeed the case, for instance, for nanocrystalline silicon when the dangling bonds are not restored by hydrogen. 
We will show, here, two favorable situations for which photoelectrochemical cells using porous nanocrystalline films have low recombination losses. These situations are depicted below.

\section{A. Feasibility of efficient photoelectrochemical cells with the EncSS structure (where EncSS stands for electrolyte - nanocrystallized semiconductor - semiconductor)}

Photoelectrochemical cells based on narrow band gap and high carrier mobility n-type semiconducting electrodes (such as $\mathrm{Si}, \mathrm{GaAs}, \mathrm{CdSe}_{1-\mathrm{x}} \mathrm{Te}_{\mathrm{x}}$, $\mathrm{CulnSe}_{2}$ ), are very attractive in the conversion of solar energy into electrical and/or chemical energy. They permit the use of economical polycrystalline or amorphous semiconductors and can give conversion efficiencies as high as those of the corresponding solid junction photovoltaic solar cells.

The main obstacle for producing such efficient photoelectrochemical systems is the photocorrosion of the n-type semiconducting photoelectrodes in contact with most aqueous electrolytes.

For instance, fig. 3 depicts the photocorrosion reaction occuring in a photoelectrochemical cell using $\mathrm{IO}_{3}^{-} / \pi^{-}$aqueous electrolyte and having $\mathrm{n}$-GaAs photoelectrode. This photocorrosion is unfortunate since a solar-to-electrical conversion efficiency over than $10 \%$ can be obtained [4]. We see in the figure that the holes, photogenerated at the GaAs surface, cause the photoelectrode decomposition according to reaction (i), instead of oxidizing the reduced species in the electrolyte according to reaction (ii).

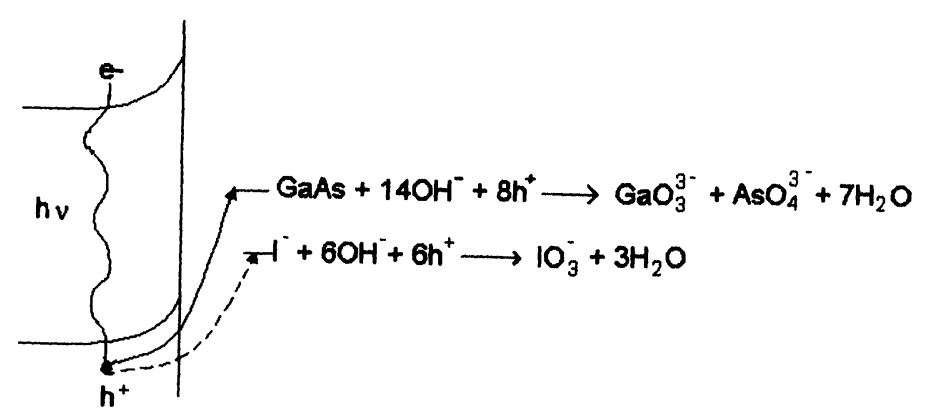

FIGURE 3 Photocorrosion reaction occuring in a photoelectrochemical cell having $n-G a A s$ photoelectrode (electrolyte: $0.1 \mathrm{M} \mathrm{I}^{-} / \mathrm{IO}_{3}{ }^{-}+0.1 \mathrm{M} \mathrm{KOH}$ ) 
Different approaches have been explored to solve the photocorrosion problem occurring in photoelectrochemical cells based on narrow bandgap semiconductors:

1. Stabilization of the photoelectrode against photocorrosion in aqueous solutions by surface coating with thin metal films, oxide films, conducting polymers, and covalently attached electroactive species [5].

2. Use of fast redox couples and treatment of the electrode surface with noble metal cations.

3. Use of non-aqueous solvents, molten salts, or solid polymer electrolytes [6].

Among these approaches, the most attractive one would concern photoelectrochemical systems based on n-type photoelectrodes coated with highly conducting oxide films since high photoconversion efficiencies are obtained. For instance, a $10 \%$ photoconversion efficiency is observed for $\mathrm{n}$-Si photoelectrodes coated with $\mathrm{n}^{+} \mathrm{SnO}_{2}$, with the corresponding hybrid electrode immersed in an $\mathrm{I}_{2} / \mathrm{I}^{-}$aqueous electrolyte. However, these photoelectrochemical systems can, in fact, be likened to solid state photovoltaic systems since the photoactive junction, responsible for the high efficiency, is the photoelectrode/oxide coating junction.

We will see, here, that high photoconversion efficiencies can be obtained without noticeable photocorrosion for photoelectrochemical cells, using $\mathrm{IO}_{3}{ }^{-} / \mathrm{I}^{-}$aqueous electrolyte, and having $\mathrm{n}-\mathrm{GaAs}$ photoelectrode coated with porous nanocrystalline n-type semiconducting $\mathrm{SrTiO}_{3}$ film (fig. 4).

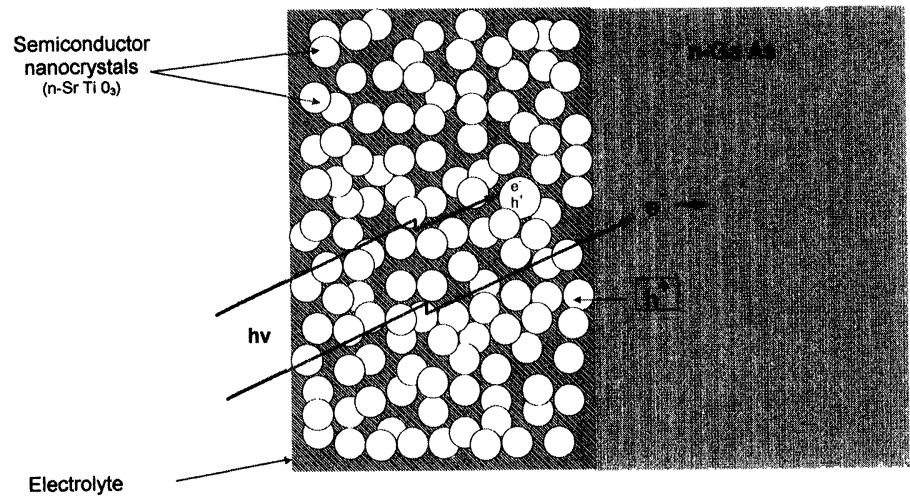

FIGURE 4 Picturial illustration of the $\mathrm{n}$-GaAs photoanode coated with porous nanocrystallite n-type $\mathrm{SrTiO}_{3}$ film 
Figure 5 shows, indeed, the variation of the short-circuit photocurrent, Isc, as a function of irradiation time and for comparison, the behavior of uncoated $\mathrm{n}-\mathrm{GaAs}$ in the same electrolyte is also shown: the $\mathrm{n}-\mathrm{GaAs} / \mathrm{SrTiO}_{3}$ electrode shows, indeed, good stability during $100 \mathrm{~h}$, while the uncoated $\mathrm{n}-\mathrm{GaAs}$ electrode undergoes photocorrosion. The charge passed in the $\mathrm{SrTiO}_{3}$ coated n-GaAs electrode during its stable period is about $1080 \mathrm{C} . \mathrm{cm}^{-2}$. It corresponds to a $14 \%$ photoconversion efficiency for an open circuit voltage Voc $\cong 1 \mathrm{~V}$ (fig. 6).

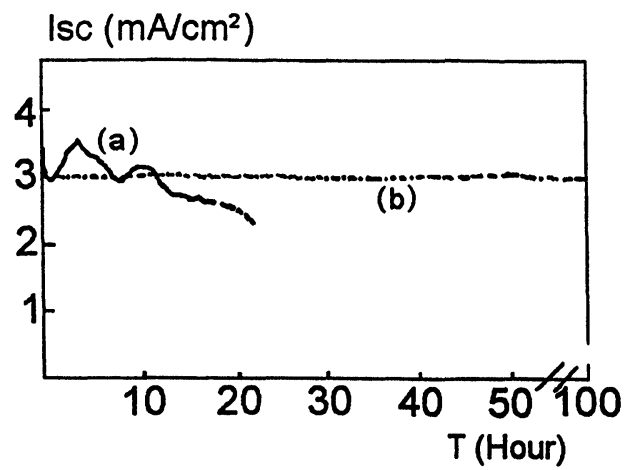

FIGURE 5 Photocurrent stability for (a) an uncoated $\mathrm{n}-\mathrm{GaAs}$ electrode and (b) $\mathrm{n}-\mathrm{GaAs} / \mathrm{SrTiO}_{3}\left(600 \mathrm{~nm}\right.$ ) hybrid electrode (electrolyte: $0.1 \mathrm{M} \mathrm{I}^{-} / \mathrm{IO}_{3}^{-}+0.1 \mathrm{M} \mathrm{KOH}$; solar light irradiation $=15 \mathrm{~mW} / \mathrm{cm}^{2}$ )

\section{I (mA / cm²)}

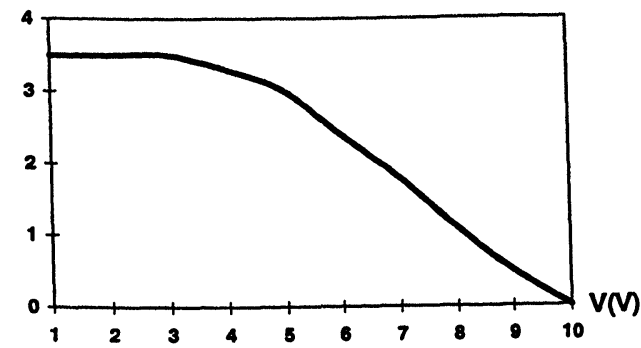

FIGURE 6 Output-power characteristics: variation of the photocurrent vs. cellpotential; the photoanode is the $\mathrm{SrTiO}_{3}$ coated $\mathrm{n}-\mathrm{GaAs}$ electrode solar light irradiation $=15 \mathrm{~mW} / \mathrm{cm}^{2}$ )

\section{How does the cell work?}

One has to quote, first, that the oxide coating must be permeable with regard to the electrolyte. Therefore the effective photoreactive junction, responsible for the $14 \%$ photoconversion efficiency, is the GaAs / electro- 
lyte junction and not the $\mathrm{SrTiO}_{3}$ / electrolyte junction: the later junction gives in rise to low photoconversion efficiencies due to high recombination rates of the photogenerated carriers [7].

One must also point out that deep subbandgap energy states exist in the $\mathrm{n}-\mathrm{SrTiO}_{3}$ film: they arise from its nanoscale structure (their nature will be discussed further on in this paper). These deep subbandgap energy states play a predominant role in the photoelectrochemical process: the holes that are photogenerated at the GaAs surface are pushed away from it (fig. 4), and directed into the deep subbandgap states present in the $\mathrm{SrTiO}_{3}$ film ; they can react afterwards with the electrolyte. The GaAs surface is not, thereby, photocorroded.

That occurs owing to

i. the chemical bond attachment between $\mathrm{GaAs}$ and $\mathrm{SrTiO}_{3}$,

ii. the probable downwards band-bending that exist at the $\mathrm{SrTiO}_{3}$ surface in contact with GaAs (fig. 7).

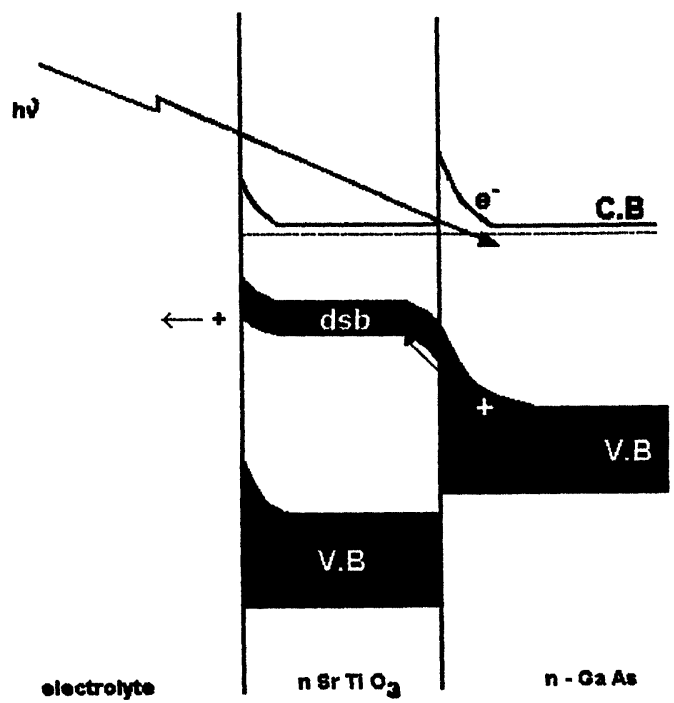

FIGURE 7 Simplified band-energy scheme showing the photohole transfer from the GaAs valence band (VB) to the $\mathrm{SrTiO}_{3}$ deep subbangap energy states (dsb)

In contrast to conventional photoelectrochemical cells, the present system separates the functions of (i) photogenerated electron-hole pair separation, taking place at the GaAs surface, and (ii) photohole reaction with the electrolyte occurring at the $\mathrm{SrTiO}_{3}$ film surface in contact with the electrolyte. 
The photoholes originating from GaAs, which cross the $\mathrm{SrTiO}_{3}$ nanocrystallites via the subbangap energy states, are the unique photogenerated carriers present in the film. Consequently, they will not recombine with the photoelectrons and, thereby, can react with the electrolyte as mentioned above. Correspondingly, the photoelectrons "ignore" the $\mathrm{SrTiO}_{3}$ film and therefore "ignore" the photoholes, so that they can easily cross the GaAs semiconductor and reach the external circuit where electrical work is done. The operation can be then closed according to fig. 2 .

We believe that the deep subbandgap levels in the film are of Ti: $3 \mathrm{~d}\left(\mathrm{t}_{2 \mathrm{~g}}\right)$ and $0: 2 p$ character: they originate from dangling bonds or oxygen chemisorption or oxygen at lower coordination sites than in the bulk $[7,8]$. The corresponding illustrative energy diagram, shown in fig. 8, serves to show that ions at defect sites on oxide surfaces see a very different environment from those on nearly perfect surfaces; one result may be to stabilize charge configurations that are normally found in the bulk: for example $\mathrm{O}^{-}$may be the usual form of oxygen at some low coordination sites [9].

(a)

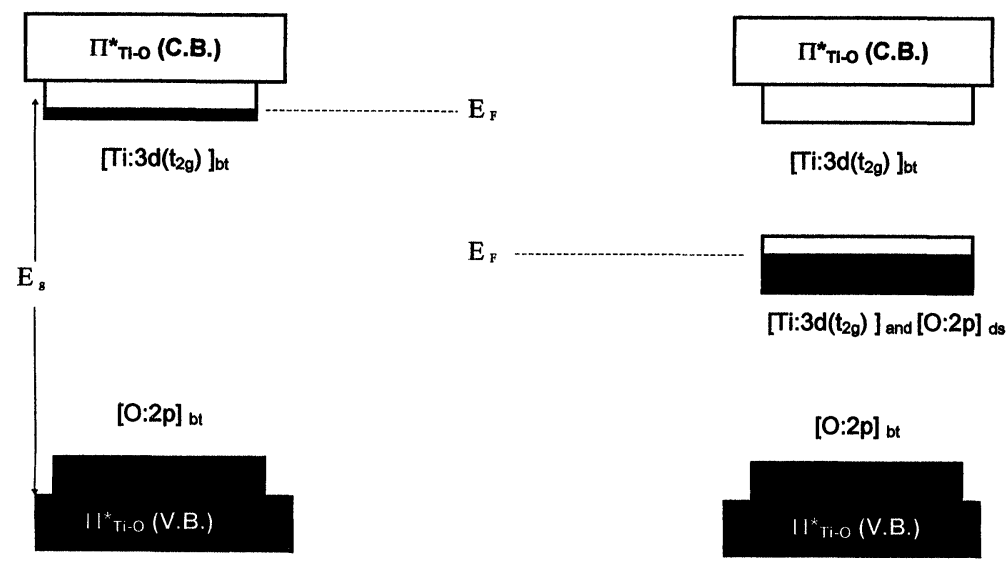

FIGURE 8 Simplified band-energy scheme of nanocrystalline n-SrTiO ${ }_{3}$ films. (a) nearly perfect crystallite surface, (b) actual crystallite surface. The titanium and oxygen bt (band-tailing) ([Ti:3d(t $\left.\left.t_{2 g}\right)\right]_{b t}$ and $\left.(O: 2 p]_{b t}\right)$ energy states originate from $T i$-O bond weakening, or decrease of the Madelung potential, at surface sites. The [Ti:3d( $\left.\left.t_{2 g}\right)\right]_{d s b}$ and $[O: 2 p]_{d s b}$ energy states represent the deep subbandgap energy states $(d s b)$, which originate from dangling bonds or oxygen chemisorption, or oxygen at lower coordination sites than in the bulk $[7,8]$ 
B. Feasibility of efficient photoelectrochemical cells with the EDncS structure (where EDncS stands for Electrolyte - Dye - nanocrystallized Semiconductor)

These new type of cells proposed for the first time by $\mathrm{M}$. Grätzel and co-workers is even more attractive than the previous one, due to their:

i. easy and cheap manufacturing process

ii. semi-transparency and smartness, so they can be advantageously used as windows, in buildings for instance

iii. overall light-to-electrical energy conversion close to that of conventional photovoltaic silicon cells (fig. 9)

iv. long term photoelectrochemical stability [3]

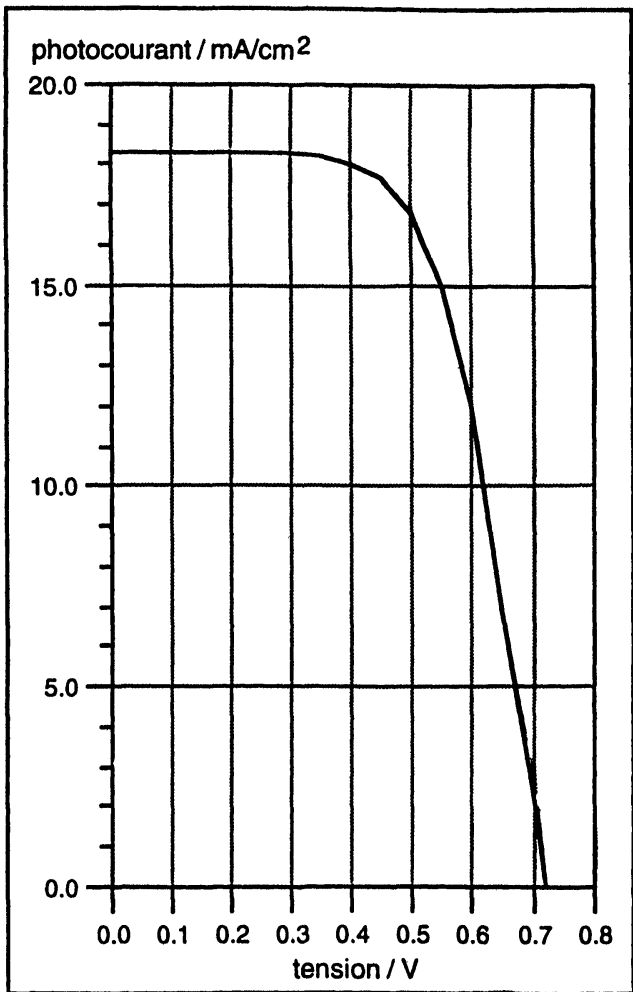

FIGURE 9 I-V Characteristic of M. Grätzel and coworkers cell. $\mathrm{I}_{\text {soler light }}=96.4 \mathrm{~mW} / \mathrm{cm}^{2}$. $\mathrm{FF}=0.69 ; \eta=8.8 \%,[3]$ 


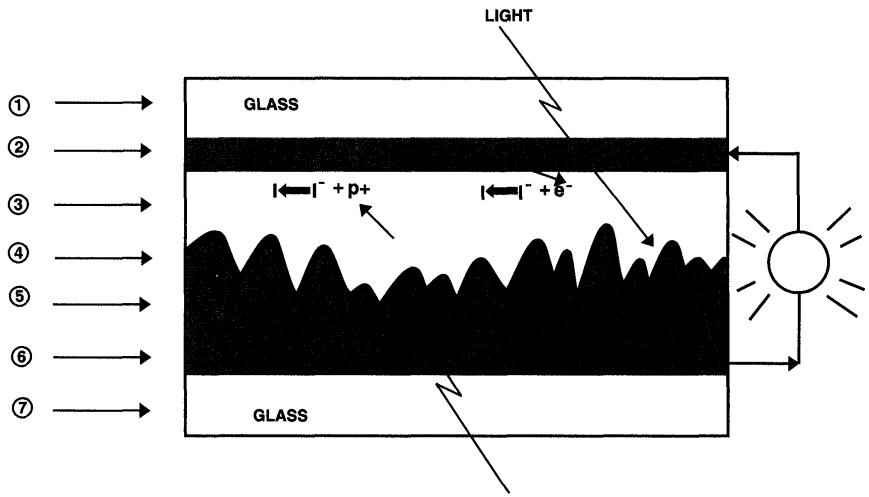

FIGURE 10 Pictorial illustration of $\mathrm{M}$. Grätzel and coworkers cell module [3]. 1 and 7: glass sheets: 2 and 6: transparent-metallic layers; $3: \mathrm{I}^{-} / \mathrm{I}_{3}^{-}$electrolyte; 5: colloidal $\mathrm{TiO}_{2}$ membrane; 4: dye stuff

The pictorial illustration of the cell module is shown in fig. 10 .

A transparent $\mathrm{TiO}_{2}$ film has been sol-gel coated on a conducting glass support: the film is composed of nanometer sized particles as shown in fig. 11 .

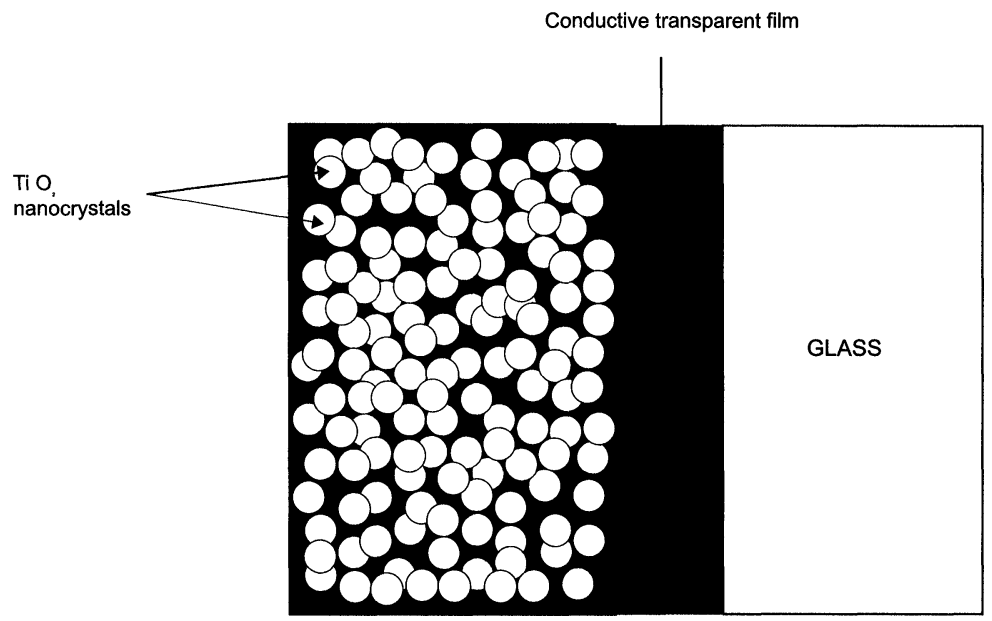

FIGURE 11 Pictorial illustration of the nanocrystalline $\mathrm{TiO}_{2}$ film, sol-gel coated on a conducting glass support 
The particles are sintered together to allow for efficient electronic conduction through the crystallites. M. Grätzel and co-workers showed, thereby, that a nanoporous structure with a high effective surface area was formed: a $10 \mu \mathrm{m}$ thick film of such a colloidal structure offers an effective surface area 1000 times greater than that of a smooth membrane [3]. Once coated on the conducting glass support, the nanosized particles are covered by a monolayer of sensitizer (fig. 10). The electronic working principle of the module is depicted on fig. 12. The originality of this new nanostruc-

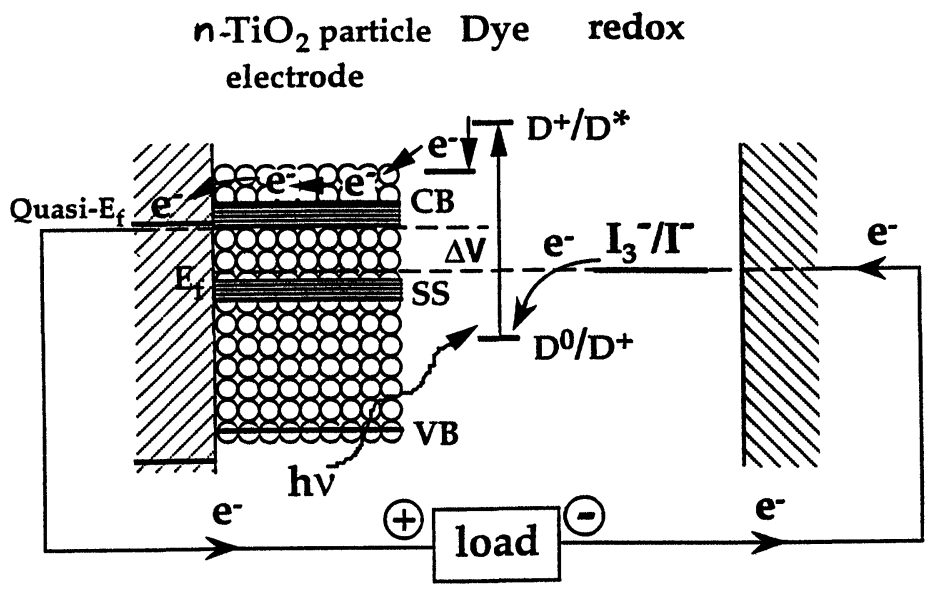

FIGURE 12 Electronic working principle of M. Grätzel cell module [3]

tured device lies in the fact that it separates the function of light absorption and carrier transport, in contrast to conventional photovoltaic cells: the sensitizer absorbs, indeed, the solar light, thereby generating photoelectron-hole pairs; before recombination takes place, the photoelectrons are pushed away from the sensitizer into the conduction band of the nanocrystalline $\mathrm{TiO}_{2}$ film. As it occurred for the nanocrystalline $\mathrm{SrTiO}_{3}$ film in the previous cell, the carriers injected here in the $\mathrm{TiO}_{2}$ film will not recombine because (i) percolation occurs between the nanocrystallites and (ii) the carriers originate from an external source, i.e., the sensitizer. Consequently electrical work can be done (fig. 10 and 12). M. Grätzel et al. showed that the huge internal surface area of the $\mathrm{TiO}_{2}$ film allowed to solve the problem of insufficient light absorption by the monomolecular layer of the sensitizer. Therefore, as pointed out above, the energy conversion efficiency is close to that of a silicon cell (fig. 9). 
We have reported on two significant examples showing how porous nanocrystalline semiconductor films can be efficiently used in photoelectrochemical cells. We will see now how nanocrystalline powders or films can be used in rechargeable lithium batteries.

\section{USE OF THE NANOCRISTALLINE MATERIALS FOR THE ELECTRICAL ENERGY STORAGE IN RECHARGEABLE LITHIUM BATTERIES}

The technologies of primary (non-rechargeable) and secondary (rechargeable) lithium batteries have been developed in parallel to the developments in the microelectronic industry for about 20 years [10]. The lithium batteries can be the lightest and most compact power sources when they are intended for portable equipments such as watches, calculators, cameras, cordless telephones, computers, and so on.

During the past 10 years, the worldwide "green revolution" has requested a new, clear, and noiseless system of energy storage for replacing petroleum-based energy sources. Rechargeable lithium batteries as high-power and high-energy/density devices can also meet the requirements of a clear and noiseless energy source, especially in the development of electric vehicles. Consequently, rechargeable lithium batteries with high power and long-life cycles have been very attractive to research groups all over the world [10]. For sake of clarity, we have shown in fig. 13 the pictorial illustration of the working principle of a secondary lithium battery. The battery voltage arises from the work function difference between the lithium anode and the cathode $\mathrm{Li}_{\mathrm{y}-\mathrm{x}} \mathrm{MO}_{2}$, whose structure (lamelar or tunnel) is adapted to reversible $\mathrm{Li}^{+}$(de)intercalation (fig.). The discharging process of the battery corresponds to the $\mathrm{Li}^{+}$ion insertion in the cathode material ( $x$ decreases). It generally decreases the cathode work function; therefore the voltage battery decreases. A reverse event occurs during the charging process (fig.).

The highest voltages can be achieved with lithium batteries using lithium metal as anode due to its lowest work function. However, the use of lithium metal as the negative electrode in rechargeable cells introduces some problems. First, the dendritic deposition of lithium metal upon recharging causes intemal short-circuits and occasionally may cause 
explosion of these cells. Second, the freshly deposited lithium dendrites react with the electrolyte and become isolated from the bulk lithium metal resulting in lower coulombic efficiencies of lithium electrodes and poor cycling life. These problems can be circumvented if another lithium intercalation compound is used as the negative electrode instead of the limited rechargeability and the safety hazards of lithium metal.

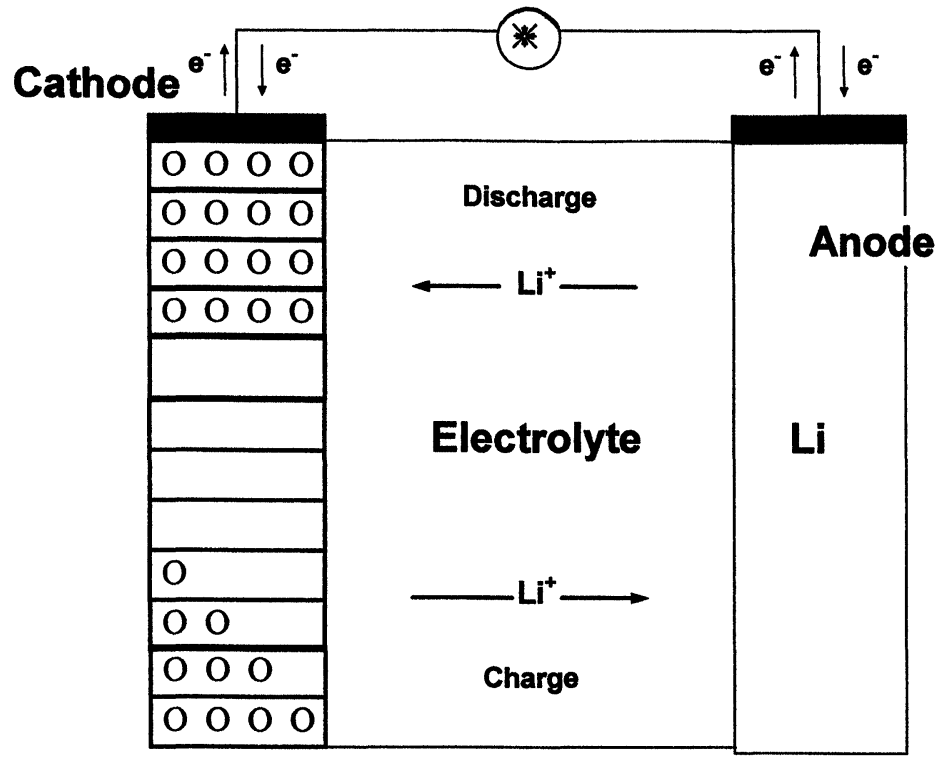

$\mathrm{Li}_{\mathrm{y}-\mathrm{x}} \mathrm{MO}_{2}$

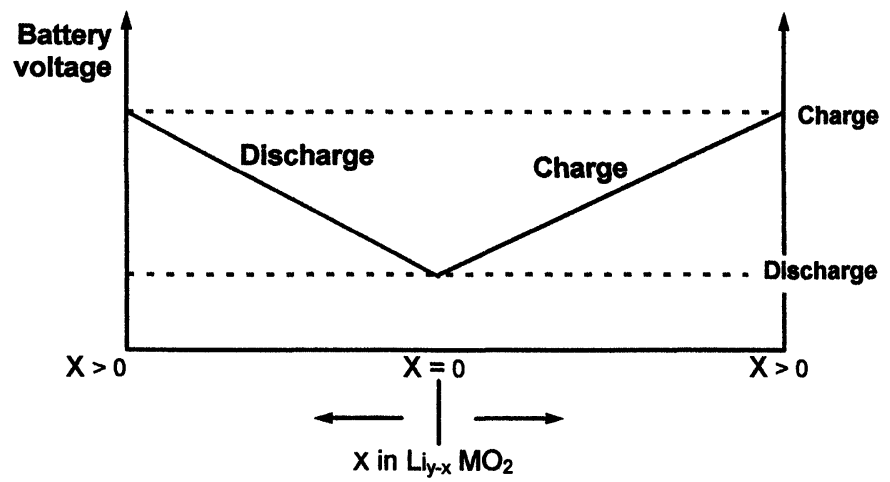

FIGURE 13 Illustration of the working principle of a secondary lithium using $\mathrm{Li}_{\mathrm{y}-\mathrm{x}} \mathrm{MO}_{2}$ as a cathode $(\mathrm{M}=\mathrm{Ni}, \mathrm{Co}, \mathrm{Mn}, \ldots[10])$ 
Consequently lithium ion batteries, such as $\mathrm{Li}_{\mathrm{x}} \mathrm{C} / \mathrm{Li}_{1-\mathrm{x}} \mathrm{CoO}_{2}$, $\mathrm{Li}_{\mathrm{x}} \mathrm{C} / \mathrm{Li}_{1-\mathrm{x}} \mathrm{NiO}_{2}, \mathrm{Li}_{\mathrm{x}} \mathrm{C} / \mathrm{Li}_{1-\mathrm{x}} \mathrm{Mn}_{2} \mathrm{O}_{4}$, so called "rocking-chair" batteries because two intercalating materials are faced, present a challenging concept : they remove, indeed, the problem of dendrite regrowth at the $\mathrm{Li}$ electrode, which may cause the explosion of the battery, by using coke or graphite as the anode instead of lithium metal [11]. Moreover, the battery potential remains high : as shown in fig. 14, the cathodes provide, indeed a working voltage of about $3.5 \mathrm{~V}$ vs carbonaceous anodes. Such a high working voltage mainly arises from the highest electron affinity of the $\mathrm{Co}^{3+} /{ }^{4+}$ (for $\mathrm{Li}_{1-\mathrm{x}} \mathrm{CoO}_{2}$ ), $\mathrm{Ni}^{3+} /^{4+}$ (for $\mathrm{Li}_{1-\mathrm{x}} \mathrm{NiO}_{2}$ ), $\mathrm{Mn}^{3+} /{ }^{4+}\left(\right.$ for $\mathrm{Li}_{1-\mathrm{x}} \mathrm{Mn}_{2} \mathrm{O}_{4}$ ).
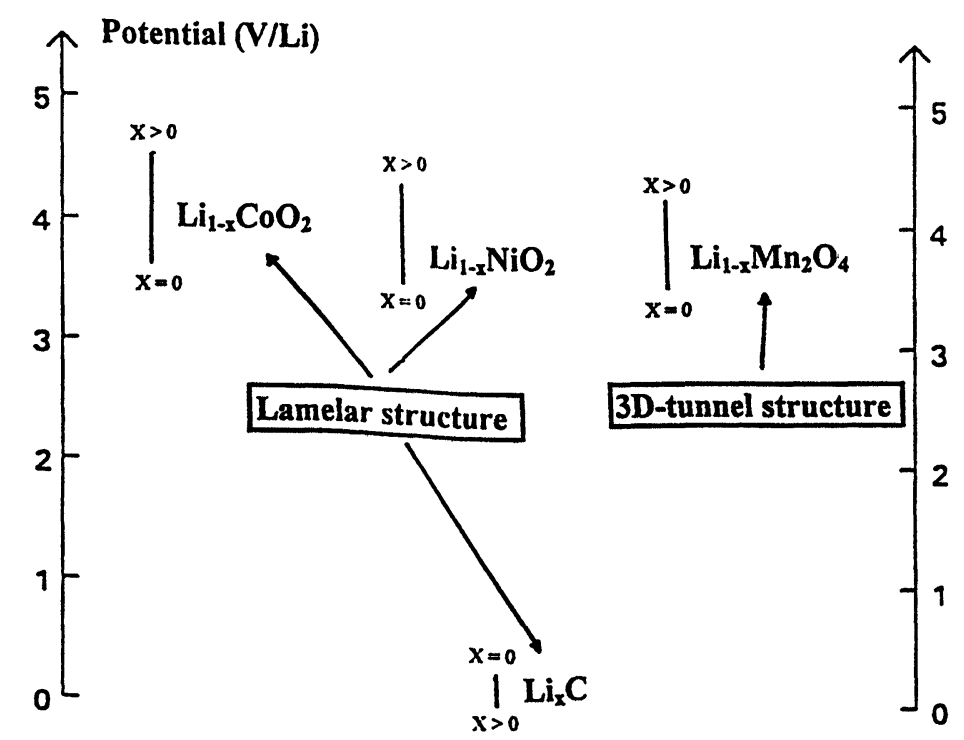

FIGURE 14 Comparison between the open circuit potentials of the electrode materials generally used in "rocking-chair" systems.

$\mathrm{Li}_{1-x} \mathrm{CoO}_{2}, \mathrm{Li}_{1-x} \mathrm{NiO}_{2}$ and $\mathrm{Li}_{X} \mathrm{C}$ on the one hand, and $\mathrm{Li}_{1-x} \mathrm{Mn}_{2} \mathrm{O}_{4}$ on the other hand, possess a layered host or a $3 \mathrm{D}$ tunnel host structure adapted to reversible $\mathrm{Li}^{+}$(de)intercalation

Moreover, the specific capacity and energy density of the batteries are much higher than that of Ni-Cd system, lead-acid system, and other rechargeable batteries [12].

Now, a question arises: can the performances of these above mentioned rocking-chair batteries be enhanced?

Eight years ago [13], when we started our research on the nanosized particle electrodes, the sizes of crystallites were generall in the micro-scale 
region. The achievement of well crystallized electrodes - having thereby a lamelar or 3D tunnel host structure (fig. 14) - was indeed a key factor determining the specific capacity.

The general assumption was indeed the following:

i. the formation of structural defects or distortions at the surface layer of crystallites is more obvious in the nanoscale region than in the microscale region;

ii. these defects and distortions would inhibit the intercalation or deintercalation processes for lithium ions.

Contrary to general expectation, we established, using many examples (fig. 15), that the insertion or deinsertion ratio is much higher in nanosized particle materials than in microsized ones. In this event, the surface defects such as anions adjacent to cation vacancies play an unnegligible role: these defects can act as reversible insertion / deinsertion sites for lithium ions. This can also favor power density and cycle life of the electrode materials $[13,14]$.

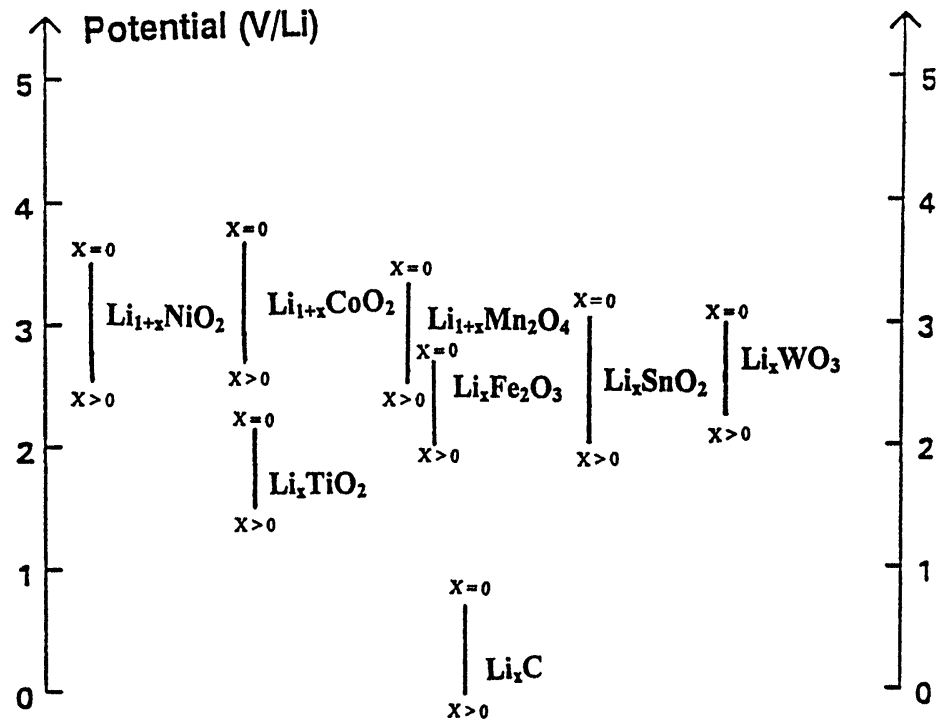

FIGURE 15 Comparison between the open circuit potentials of different nanosized-particle electrode materials, prepared and studied at the ICMCB $(0 \leq x \leq 0.8$ for most of materials $)$

As a non-limiting but illustrative example, fig. 16 shows the better reversibility and storage capacity of $\mathrm{Li}^{2} \mathrm{LiPF}_{6}, \mathrm{EC}: \mathrm{DMC} / \mathrm{TiO}_{2}$ (anatase) 


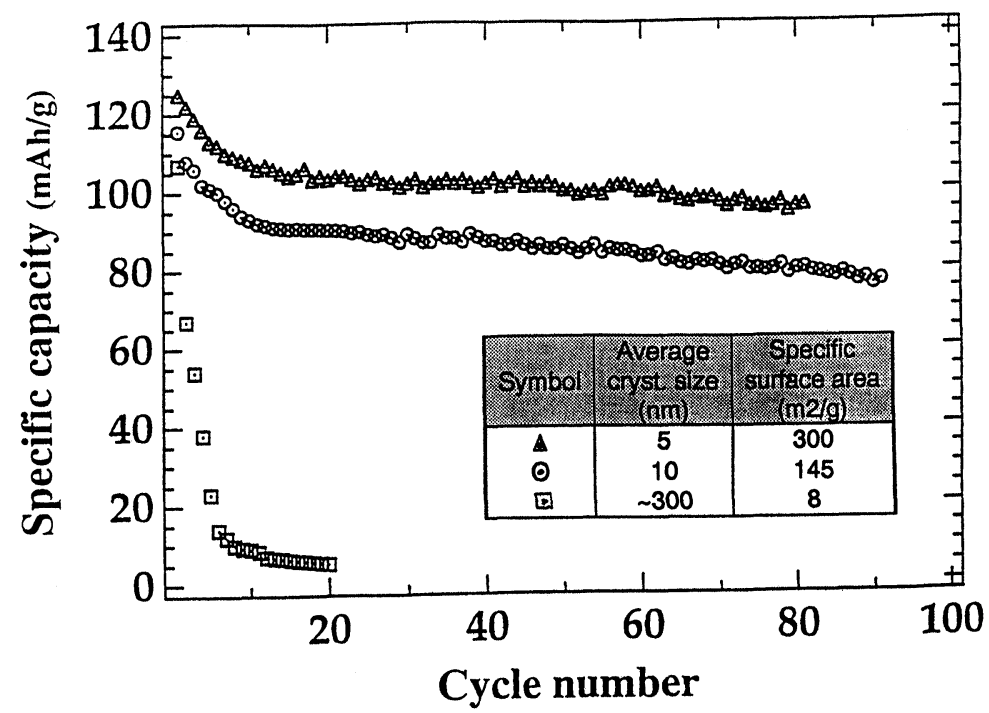

FIGURE 16 Cyclability and storage capacity of the $\mathrm{Li} / \mathrm{Li} \mathrm{PF} 6$, EC: $\mathrm{DMC} / \mathrm{TiO}_{2}$ cells with nanoscale and microscale powder. $\left(\mathrm{J}=1.30 \mathrm{~mA} / \mathrm{cm}^{2}\right.$ for $25 \mathrm{mg} \mathrm{TiO}{ }_{2} ; \mathrm{EC}=$ ethylene carbonate $\mathrm{C}_{3} \mathrm{H}_{4} \mathrm{O}_{3} ; \mathrm{DMC}=$ demethyl carbonate $\left.\left(\mathrm{CH}_{3} \mathrm{O}\right)_{2} \mathrm{CO}\right)$

cells with nanosized powder and microsized powder: the nanosized materials exhibit a rather good electrochemical cyclability. In contrast, the initial capacity of microsized electrodes cannot be repeated at all.

We have demonstrated the feasibility of this concept by manufacturing rechargeable $\mathrm{Li}$-ion polymeric batteries using $\mathrm{Li}_{1+\mathrm{x}} \mathrm{Mn}_{2} \mathrm{O}_{4}$ and $\mathrm{Li}_{\mathrm{x}} \mathrm{C}$ with nanosized particles (fig. 17). They have, indeed, enhanced specific capacity [15].

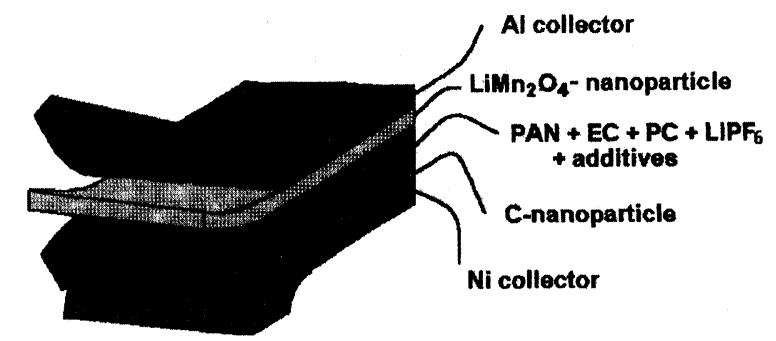

The polymeric battery

FIGURE 17 The Li-ion polymeric battery 
For instance, by using disordered graphite with nanosized particles, the anode capacity can be enhanced from $340 \mathrm{Ah} / \mathrm{kg}$ to $600 \mathrm{Ah} / \mathrm{kg}$ [16]. That is an important finding: a recent overheat incident of $\mathrm{Li}_{\mathrm{x}} \mathrm{C} / \mathrm{Li}_{1-\mathrm{x}} \mathrm{CoO}_{2}$ battery in the Apple Power Book 5300 portable computer warns, indeed, that safety is still not satisfactory [17]. When microsized graphites are fully intercalated with lithium, leading to the composition $\mathrm{LiC}_{6}$, they reach voltages within a few millivolts of metallic $\mathrm{Li}$. This means that $\mathrm{LiC}_{6}$ is as reactive as metallic $\mathrm{Li}$. Like metallic $\mathrm{Li}$, reactions between $\mathrm{LiC}_{6}$ and organic electrolytes begin at much lower temperature than its melting point, although the melting point of $\mathrm{LiC}_{6}\left(700^{\circ} \mathrm{C}\right)$ is much higher than that of metallic $\mathrm{Li}\left(180^{\circ} \mathrm{C}\right)$. These reactions may cause overheating or damage of the electrode as well as the battery. On the other hand, by using disordered graphite with nanosized particles, it has been quoted above that the anode capacity can be enhanced dramatically. In this case, half of the intercalation process will supply sufficient anodic capacity to the battery, while the anodic potential remains high enough to ensure electrode safety.

However, all the above assertions are mainly valid for nanocrystalline electrode materials, such as those quoted in fig. 15, for which the grafting process of $\mathrm{Li}^{+}$ions on crystallite surface defects (such as dangling bonds) takes place prior to any other $\mathrm{Li}^{+}$(de)insertion process. Consequently, the surface defects are annihilated and, thereby, do not inhibit the $\mathrm{Li}^{+}$intercalation within the crystallites. In the following deinsertion step, the deintercalation of the $\mathrm{Li}^{+}$ions from the bulk of the crystallites occurs first, followed by the degrafting process of the $\mathrm{Li}^{+}$ions from the surface. The reversible electrochemical cycling can then be repeated, advantageously combining surface effects and bulk effects.

Such a favorable situation does not exist for electrode materials, such as $\mathrm{Li}_{1-\mathrm{x}} \mathrm{Mn}_{2} \mathrm{O}_{4}, \mathrm{Ii}_{1-\mathrm{x}} \mathrm{NiO}_{2}$, or $\mathrm{Li}_{1-\mathrm{x}} \mathrm{CoO}_{2}$ (fig. 14), for which the electrochemical cycling begins with the deinsertion of the $\mathrm{Li}^{+}$ions. This deinsertion process can then be inhibited by the surface defects [15]. Their density must, thereby, be minimized either by increasing the size of crystallites or by having nearly perfect crystallite surfaces. At the present time, we are precisely focusing our efforts on the synthesis of nanocrystalline materials having nearly perfect crystallite surfaces.

We believe that rocking-chair lithium ion batteries based on nanocrystalline materials might be the next generation of rechargeable batteries showing higher capacity, cyclability, and safety than conventional lithium ion batteries. 


\section{USE OF NANOCRYSTALLINE FILMS FOR THE CONTROL OF LIGHT TRANSMISSION IN ELECTROCHROMIC WINDOWS (ECW).}

Electrochimichromism (so called electrochromism, here, for sake of simplicity) is the phenomenon related to changes in color occurring in thin film materials, so called ECM (for electrochromic materials). This change in color is induced by a reversible electrochemical process such as the $\mathrm{Li}^{+}$ electrochemical insertion in the films (situation considered here).

Although the ECMs include not only inorganic but also organic compounds, we will focus uniquely on inorganic compounds, more particularly on oxides. They can be divided into two classes:

a. The oxides with "cathodic coloration", such as $\mathrm{WO}_{3}, \mathrm{MoO}_{3}, \mathrm{TiO}_{2}$ [18]. In the following, they will be symbolized as $\mathrm{ECM}_{1}$. Their conductivity tends to increase upon $\mathrm{Li}^{+}$insertion. For instance, one has

$$
\begin{array}{ccc}
\mathrm{WO}_{3}+\mathrm{x} \mathrm{Li}^{+}+\mathrm{x} \mathrm{e}^{-} & \Leftrightarrow & \mathrm{Li}_{\mathrm{x}} \mathrm{WO}_{3} \\
\text { colorless } & & \text { blue } \\
\text { low conductivity } & & \text { high conductivity }
\end{array}
$$

The oxides with "anodic coloration", such as $\mathrm{Li}_{2} \mathrm{NiO}_{2}, \mathrm{LiCrO}_{2}[18,19]$, symbolized as $\mathrm{ECM}_{2}$ below. Their conductivity tends to decrease upon $\mathrm{Li}^{+}$ insertion.

$$
\begin{gathered}
\mathrm{Li}_{2-\mathrm{x}} \mathrm{NiO}_{2}+\mathrm{x} \mathrm{Li}^{+}+\mathrm{xe}^{-} \\
\text {brown } \\
\text { high conductivity }
\end{gathered} \quad \begin{gathered}
\begin{array}{l}
\mathrm{Li}_{2} \mathrm{NiO}_{2} \\
\text { colorless }
\end{array} \\
\text { low conductivity }
\end{gathered}
$$

or

$$
\begin{gathered}
\mathrm{Li}_{1-\mathrm{x}} \mathrm{CrO}_{2}+\mathrm{Li}^{+}+\mathrm{e}^{-} \\
\text {yellow-green } \\
\text { high conductivity }
\end{gathered} \Leftrightarrow \quad \begin{gathered}
\mathrm{LiCrO}_{2} \\
\text { colorless } \\
\text { low conductivity }
\end{gathered}
$$

Figure 18 schematically illustrates the method of operation of a ECW: it involves a $\mathrm{ECM}_{1}$ and a $\mathrm{ECM}_{2}$ (deposited on a ITO coated glass substrate), which are separated by a $\mathrm{Li}^{+}$ionic conductor $\mathrm{IC}\left(\mathrm{Li}^{+}\right)$. By applying a voltage between $\mathrm{ECM}_{1}$ and $\mathrm{ECM}_{2}$, the electrochromic process can be promoted so as to introduce coloration by (i) cathodic polarization of $\mathrm{ECM}_{1}$ (formation of colored "inserted" $\mathrm{Li}_{\mathrm{x}} \mathrm{ECM}_{1}$ ) and, consequently, by anodic polarization of $\mathrm{ECM}_{2}$ (formation of colored "deinserted" $\mathrm{Li}_{\mathrm{y}-\mathrm{x}} \mathrm{ECM}_{2}$ ). A 
reverse polarization restores the bleached state of the ECW (formation of transparent "deinserted" ECM 1 and of transparent "inserted" $\mathrm{Li}_{\mathrm{y}} \mathrm{ECM}_{2}$ ).

The ECW behaves, in fact, as a rocking chair lithium battery. The unique differences with the rocking-chair systems reported above (§III), is that thin films are concerned here. Moreover, this thin film rocking chair battery changes from the colored to the transparent state depending upon whether the battery is charged or discharged (fig 18).

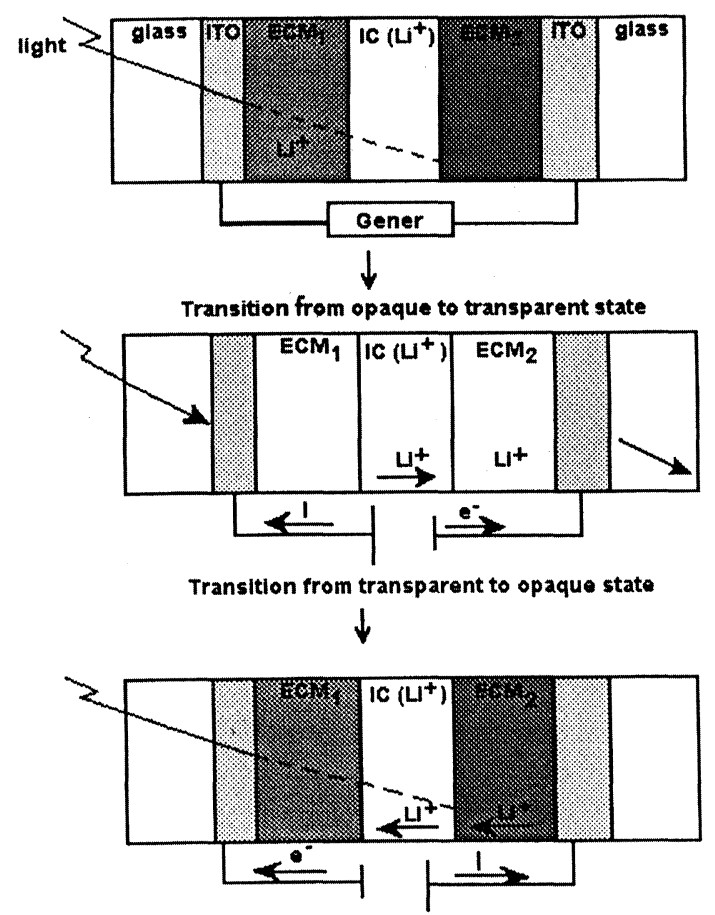

FIGURE 18 Method of operation of an electrochromic window (ECW)

Consequently, the approach developed above for obtaining highly efficient rocking chair batteries, and which consists of using nanocrystalline electrode materials, obviously applies here. Therefore, the major requirement is that the thin-film electrode materials are polycrystalline with a grain size as small as possible. Indeed, a large $\mathrm{Li}^{+}$insertion rate in the $\mathrm{ECM}_{\mathrm{s}}$ will obviously induces deep coloration changes in the ECW.

Let us recall that the electrochemical (de)insertion of $\mathrm{Li}^{+}$, associated with marked color changes, was demonstrated by numerous workers for 
some $\mathrm{ECM}_{1}$ such as $\mathrm{Li}_{\mathrm{x}} \mathrm{WO}_{3}$ or $\mathrm{Li}_{\mathrm{x}} \mathrm{MoO}_{3}$ [20], and some $\mathrm{ECM}_{2}$ such as $\mathrm{Li}_{\mathrm{x}} \mathrm{IrO}_{2}$ [21]. However, we have clearly shown the importance of the nanocrystalline texture for most of $\mathrm{ECM}_{\mathrm{s}}$. Moreover, this concept allows us to propose a simple model for describing the electrochimichromic properties of the nanocrystalline $\mathrm{ECM}_{\mathrm{s}}$. The framework of this model is given below using $\mathrm{TiO}_{2}$ as an illustrative (but not limiting) example.

First of all, when cathodic and anodic bias are applied to the nanocrystalline $\mathrm{TiO}_{2}$ films, coloration and bleaching phenomena are altematively observed, according to:

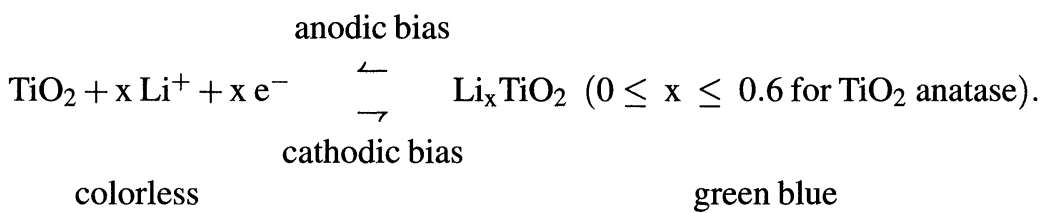

The following two processes, depicted on fig. 19, account for the colorless to green blue coloration change (cathodic bias).

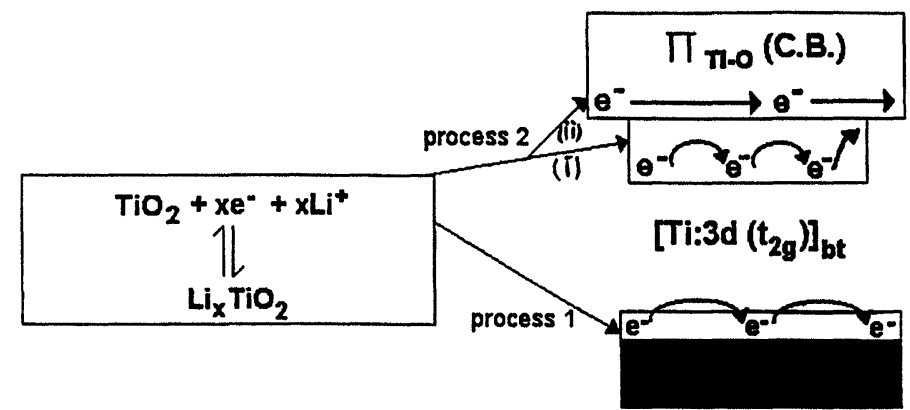

$\left[T i: 3 d\left(t_{2 g}\right)\right]$ and $[0: 2 p]_{d s b}$

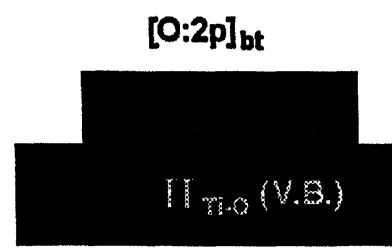

FIGURE 19 Visualization of the electrochemical process accounting for the electronic (electrical and optical) properties of the nanocrystalline $\mathrm{TiO}_{2}$ films 


\section{Process 1: light absorption process for low $\mathrm{x}$ values}

The Fermi energy lies in the band of the $[\mathrm{Ti}: 3 \mathrm{~d}]_{\mathrm{dsb}}$ and $[\mathrm{O}: 2 \mathrm{p}]_{\mathrm{dsb}}$ localized states. The electrons, which are progressively injected in the electrode as $\mathrm{x}$ increases, move between these localized states via a phonon assisted tunnelling process [22]. Consequently, they have a low mobility so that no optical reflectivity can be observed: the observed coloration accounts indeed for a light absorption process.

\section{Process 2: light absorption + reflexion process for higher $\mathrm{x}$ values}

It occurs when all the empty $[\mathrm{Ti}: 3 \mathrm{~d}]_{\mathrm{dsb}}$ and $[\mathrm{O}: 2 \mathrm{p}]_{\mathrm{dsb}}$ states are filled with electrons. It corresponds to

i. the progressive filling, as $x$ increases, of the $\left[\mathrm{Ti}: 3 \mathrm{~d}\left(\mathrm{t}_{2 \mathrm{~g}}\right)\right]_{\mathrm{bt}}$ states, leading (mainly) to a light absorption process followed by

ii. the injection of electrons into the conduction band occurring, thereby, when all [Ti:3d $\left.\left(t_{2 g}\right)\right]$ states are occupied (highest $x$ values). That corresponds to more extended state conduction accounting for optical reflectivity.

Let us recall that process 1 and mechanism (i) in process 2 are mainly related to surface effects and grain boundary effects.

On the other hand, the electrochemical injection of carriers in the conduction band, i.e. mechanism (ii) in process 2 , corresponds to the $\mathrm{Li}^{+}$intercalation within the nanocrystallites, allowed by the 3D tunnel anatase structure of $\mathrm{TiO}_{2}$. One can easily guess that process 1 (or 2) predominates over process 2 (or 1) if the average crystallite size of the ECM is low (or high). We established, indeed, that if the crystallite size is lower than $\sim 30 \AA$, uniquely process 1 takes place, leading to fast coloration changes that are themselves related to light absorption processes [22].

Similar observations can be applied to others $\mathrm{ECM}_{\mathrm{s}}$ provided one can estimate their band structure and keeping in mind that $\mathrm{ECM}_{1}$ and $\mathrm{ECM}_{2}$ behave in a complementary way: $\mathrm{ECM}_{2}$ films change indeed from a transparent to colored state as $\mathrm{x}$ decreases, contrary to $\mathrm{ECM}_{1}$ films.

\section{Acknowledgements}

G. Campet, J. Portier and N. Treuil with to thank the «CNET (Centre National d'Etudes des Télécommunications), 92 Issy-les-Moulineaux France» for its helpful assistance and financial support. 


\section{References}

[1] a/ M.L. Steigerwald and L.E. Brus, Acc. Chem. Res., 23,183 (1990).

b/ N. Herron, J. Phys. Chem. 95, 525 (1991).

c/ L.E. Brus, J. Chem. Phys. 80, 4403 (1984).

d/ Y. Kayanuma, Phys. Rev. B38, 9797 (1988).

e/ Y. Kayanuma and H. Momiji, Phys. Rev. B41, 10261 (1990).

f/ P.E. Lippens and M. Lannoo, MRS Symposium Proceedings, 217 (1992).

g/ V.E. Henrich and P.A. Cox, "The Surface Science of metal oxides", Cambridge University Press (1994).

[2] a/ C. Guizard, A. Julbe, A. Larbot and L. Cot, J. of Alloys and Compounds 188, 8 (1992).

b/ A. Julbe, C. Guizard, A. Larbot, L. Cot and A. Giroir-Fendler, J. of Membrane Science, 77, 137 (1993).

c/ L. Auvray, A. Ayral, L. Cot, T. Dabadie, C. Guizard and J. Ramsey, J. Sof-Gel science and Technology, 2, 205(1994).

d/ A. Makino and C.K. Law, J. Am. Ceram. Soc. 77,778 (1994).

e/ I. Lisiecki and M.P. Pinieli, J. Phys. Chem., 99, 5077 (1995).

f/ C. Petit and M.P. Pinieli, J. Phys. Chem., 92, 2282 (1988).

g/ Y.M. Tricot and J.H. Fendles, J. Phys. Chem. , 99, 3369 (1986).

h/ J.J. Ramsden and M. Grätzel, J. Chem. Soc., Faraday Trans. 1, 80, 919 (1984).

i/ U. Ciesla et al., J. Chem. Soc., Chem. Commun. (1994).

j/ Garrabos, B. Le Neindre, P. Subra, F. Cansell and C. Pommier Ann. Chim. Fr., 17, 55 (1992).

k/ C. Pommier, K. Chhor, J.F. Bocquet, M. Barj, Mat. Res. Bull., 25, 213 (1990).

1/ J.F. Bocquet, K. Chhor and C. Pommier, Materials Chemistry and Physics, 32, 249 (1992).

m/ J.F. Bocquet, K. Chhor and C. Pommier, Surface and Coating Technology, 70, 73 (1994).

n/ S.D. Han, S. Y. Huang, G. Campet, M.A. Kennard and Y.M. Son, Active and Passive Elec. Comp., 18, 53 (1995).

o/ J. Moser and M. Grätzel, Helv. Chim. Acta., 65, 1436 (1982).

p/ G. Campet, S.J. Wen, S.D. Han, M.C.R. Shastry and J. Portier, Mater. Sci. Eng., B18, 201 (1993).

q/ K. Sato, M. Nogumi, A. Demachi, N. Oki and M. Endo, Science, 264, 556 (1994).

r/ M. Grätzel, J. Sol-Gel Science and Technology, 2, 673 (1994).

s/ R.A. Vaia, H. Ishii and E. P. Giannelis, Chem. Mater. 5, 12, 1694 (1993).

t/ L.E. Brus et al., Mater. Res., 4, 704 (1989).

[3] a/ M. Grätzel, J. Sol-Gel Science and Technology, 2, 673 (1994).

b/ M. Grätzel, The World \& I, p. 228-235 (1993).

c/ B. O'Regan and M. Grätzel, Nature, 353, 737 (1991).

d/ N.K. Nazeerudin, A. Kay, L. Rodicio, R. Humphry-Backer, E. Müller, P. Liska, N. Vlachopoulos and M. Grätzel, J. Am. Chem. Soc, 115, 6382 (1993). e/ A. Kay and M. Grätzel, J. Phys. Chem., 97, 6272 (1993).

[4] a/ P. Allongue and H. Cachet, J. Electrochem. Soc., 131, 2861 (1984). b/ P. Allongue and G. Cachet, Electrochim. Acta, 33, 79 (1988). c/ Z.W. Sun and G. Campet, Mater. Science and Eng. B5, 455 (1990).

[5] Z.W. Sun and G. Campet, Mater. Science and Eng. B5, 455 (1990) and references therein.

[6] a/ M. Miyaka, H. Honeyama and H. Tumura, Electrochim. Acta, 22 (1977) 319. b/ C.G. Gronet and N. S. Lewis, Nature, 300 (1982) 793. c/ P. Singh, K. Rajeshwar, J. Dubow and R. Job, J. Am. Chem. Soc, 102(1980) 4676. d/ T. Skotheim, Appl. Phys. Lett. 38 (1981) 712. 
[7] a/ P. Salvador, C. Gutierrez and G. Campet, J. Electrochem. Soc, 131, 550 (1984). b/ G. Campet, S.J. Wen, C. Puprichitkun, J.P. Manaud and J. Claverie, Phys. Sat. Sol. (a), 103, 175 (1987). c/ G. Campet. C. Geoffroy, J.P. Manaud and J. Portier, Mat. science and Eng. B8, 45 (1991).

[8] a/ Nanophase and Nanocomposite Materials, M.R.S. Symposium Proceedings, vol.286, S. Komarneni, J.C. Parker and G.J. Thomas Editors (1992).

b/ N.E. Cusack, The Physis of Structurally Didordered Matter, Graduate Student Series in Phisics, D.F. Brewer Editor, Adam Hilger Collection (1987).

[9] J.C. Giron, Doctorat Theses, University Paris VI, France, (1994).

[10] a/ J. Rouxel, Physica 99B, 3 (1980) and references therein. b/ M. Armand, Doctoral Thesis, Inst. National Polytech. de Grenoble (1978). c/ C. Delmas, C. Fouassier and P. Hagenmuller, J. Phys. Chem. Solids 39, 55 (1978). d/ J. Molenda, Solid States Ionics 21, 263 (1986). e/ A. Levasseur, M. Menetrier, Mar. Sci. Eng., B3, 5 (1989). f/ Z.I. Takehara and K. Kanamura, Electrochimica Acta., 38, 1169(1993). g/ K.M. Abraham, Electrochimica Acta., 38, 1233 (1993). h/ M. Broussely, F. Perton, J. Labat, R.. Staniewicz and A. Romero, J. Power Sources, 43-44, 209 (1993).

[11] a/ T. Nagaura, in proceedings of the 4th International Rechargeable Battery Seminar, Deerfield Beach, Florida, 1990. b/ J.R. Dahn, U. Von Sacken and R. Fong, paper 42 in proceedings of the 178th Meeting of the Electrochemical Society, Seattle, Washinton, 1990.

[12] a/ I. Koetschau, M.N. Richard, J.R. Dahn, J.B. Soupart and J.C. Rousche, J. Electrochemical Soc., 142 (9), 2906-2910 (1995).

b/ in Lithium Ion Battery Technology, Progress in batteries \& Battery Materials, Vol. 14. Edited by Ralph J. Brodd, ITE-JEC Press Inc. 1995.

c/ in Lithium Battery: New Materials, Development and Perspectives, Edited by G. Pistoia, Elsevier Science B.V. 1994.

[13] J.P. Couput, G. Campet, J.M. Chabagno, M. Bourrel, D. Muller, R. Garrié, C. Delmas, B. Morel, J. Portier and J. Salardenne, Int. Appl. Publ. under PCT. Int. Pat. Class GO2F 1701, FO1 G9/00, C 23C 14/34, WO 91/01510, 1989.

[14] G. Campet, S.J. Wen, S.D. Han, M.C.R. Shastry and J. Portier, Mater. Sci. Eng., B14, 201 (1993).

[15] N. Treuil, G. Campet, and J. Portier, private communication.

[16] K. Sato, M. Noguchi, A. Demachi, N. Oki and M. Endo, Science, 264, 556-558 (1994).

[17] a/ B. Tailor (Apple spokesperson), Better \& EV Technology, 10, 1995, p.2. b/ C.-K. Huang, S. Surampudi, A.I. Attia and G. Halpert, Better \& EV Technology, 9, 1995, p.3.

[18] G. Campet, J. Portier and S.J. Wen, Active and Passive Elec. Comp., 14, 225 (1992).

[19] G. Campet, J. Portier, D. Morel, D. Ferry, J.M. Chabagno and M. Bourrel, Active and Passive Elec. Comp., 14, 219 (1992).

[20] a/ B.W. Fanghnan, R.S. Crandall and P.M. Heyman, RCA Rev., , 36(1975) 177. b/ B.W. Fanghnan, R.S. Crandall and M.A. Lampert, Appl. Phys. Lett., 27 (1975) 275. c/ P. Gerard, A. Deneuville, G. Hollinger and T.M. Duc, J. Appl. Phys., 48 (1977) 4252.

d/ O.F. Schirmer, V. Wittver, G. Baw and G. Brandt, J. Electrochem. Soc., 124 (1977) 749.

e/ K.S. Kang, Ph.D. Thesis, University of London, 1979.

f/ H.M. Gupta and G.F. Leal Ferreira, J. Appl. Phys., 50 (1979) 5036.

g/ P. Gerard, A. Deneuville and R. Courths, Thin Solid Films, 71 (1980) 221.

h/ W.C. Dautremont-Smith, Displays, 4 (1982) 3.

i/ R.R. Goldner, D.H. Mendelsohn, J. Alexander, W.R. Henderson, D. Fitzpatrick, R.D. Rouh, M.A. Parker and T.L. Rose, Appl. Phys. Lett., 43 (1983) 1093. 
j/ D.H. Mendelsohn and R.B. Goldner, J. Electrochem. Soc., 131 (1984) 857

k/ C.M. Lampert, Sol. Energy Mater., 11 (1984) 1.

1/ M. Pham Thi and G. Velasco, (1985) 195.

m/ J.S.E. Svenlon and C.G. Granqvist, Thin Solid Films, 126 (1985) 31.

n/ M. Green and A. Talvos, Philos. Mag. B, 51 (1985) 501.

o/ F. Bonino, L. Peraldo Bicelli, B. Rivolta, M. Lazari and F. Festorazzi, Solid State Ion., 17 (1985) 21.

p/ H. Kaneko, F. Nagav and K. Miyake, J. Apll. Phys., 63 (1988) 510.

q/ O. Bohnke, Cl. Bohnke, A. Donnadieu and D. Davazoylen, J. Appl. Electrochem., 18 (1988) 447.

r/ R.B. Goldner, T.E. Haas, G. Seward, K.K. Wong, P. Norton, G. Foley, G. Berera, G. Wei, S. Schulz and R. Chapman, Solid State Ion., 28 (1988) 1715.

s/ M.F. Daniel, B. Desbat, J.C. Lassègues, and R. Carie, J. Solid State Chem., 77 (1988)

127.

t/ M. Green and Z. Hussain, J. Appl. Phys., 69 (1991) 7788.

[21] a/ S. Hackwood, A.H. Dauem and G. Beni, Phys. Rev. B, 26 (1982) 471.

b/ P.G. Pichup and V.I. Birss, J. Electrochem. Soc., 135, 41 (1988).

[22] G. Campet, S.J. Wen, S.D. Han, M.C.R. Shastry and J. Portier, Mater. Sci. Eng., B18, 201 (1993). 

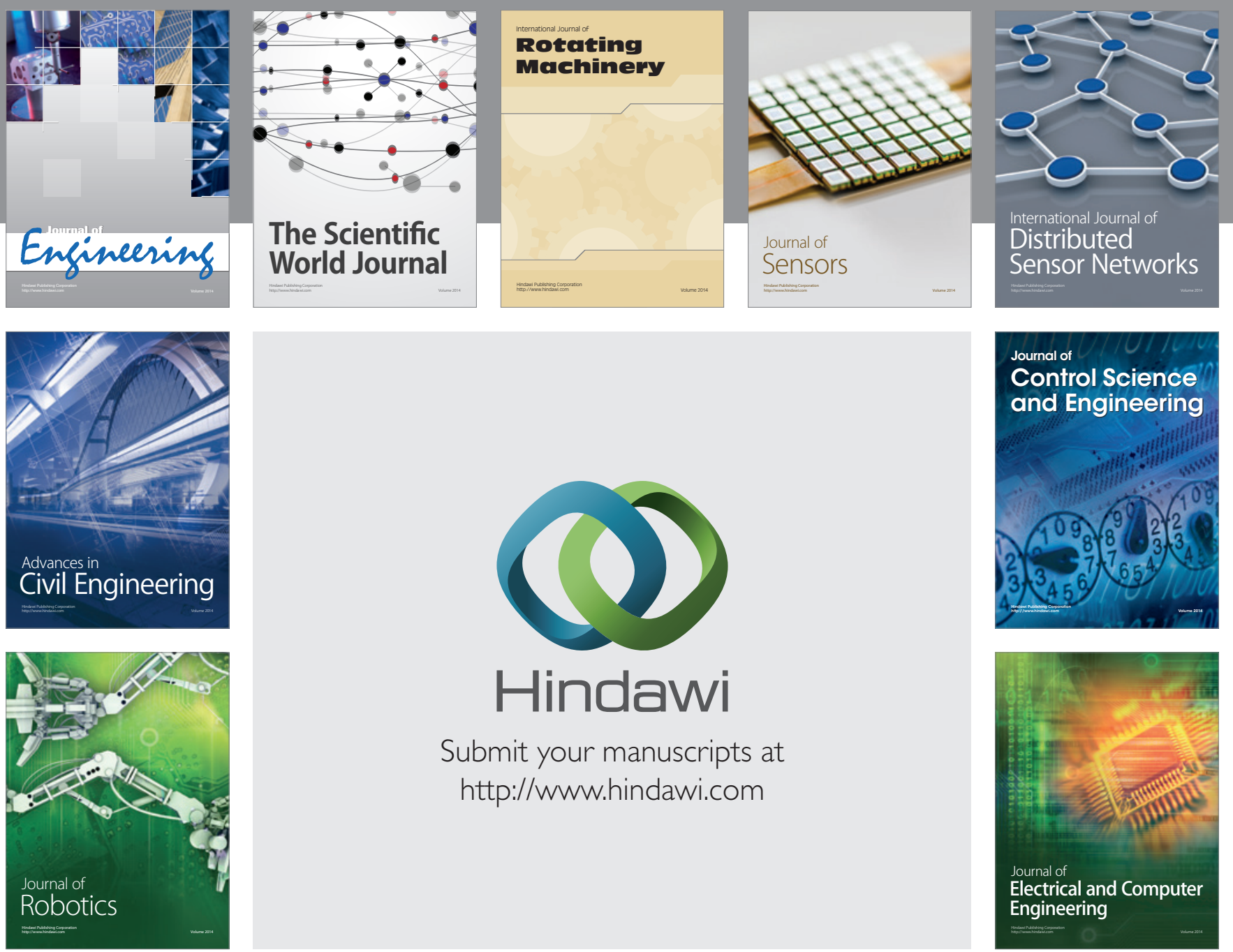

Submit your manuscripts at

http://www.hindawi.com
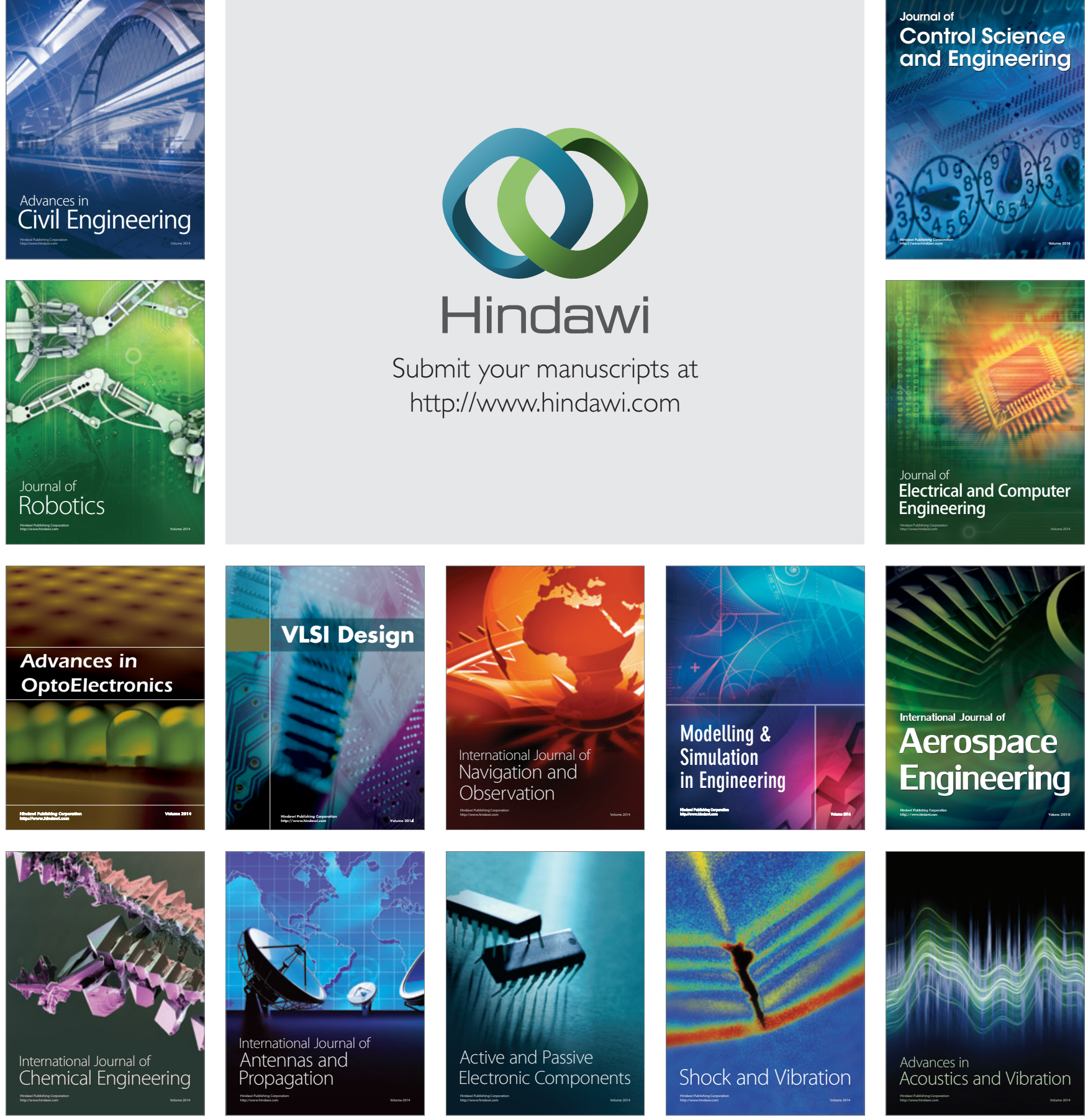